\title{
Editorial
}

\section{Interim Measures: Are Some Opportunities Worth Missing?}

\section{$1 \quad$ Introduction}

In this issue of the European Convention on Human Rights Law Review, we have the pleasure to host two guest editorial notes. Our esteemed guests, Professor Başak Çalı and Judge Armen Harutyunyan, discuss the effectiveness of the European Court of Human Rights (ECtHR, Court) in the circumstances when more and more European states are facing a real risk of becoming illiberal democracies or even outright authoritarian regimes. In this editorial note we are also considering the effectiveness of the Court, but from a different perspective. What we are briefly discussing below is the usefulness of interim measures in inter-state disputes. This is a rather controversial issue, which is reflected in the two sets of arguments, pointing in different directions, that we are presenting towards the end of this editorial note. The purpose of presenting two different points of view in this co-authored editorial note of ours is to illustrate some of the delicate trade-offs that a Court like the ECtHR might face.

More than once, authors of one of the leading blogs dedicated to the ECtHR, Strasbourg Observers, commented on case law, characterising it in the title of their notes as a 'missed opportunity' for the Court. ${ }^{1}$ Often the Convention

See, for example, N de Puy Kamp, 'Atv zrT v. Hungary: A Missed Opportunity to Address Hungary's Oppressive Media Act' (Strasbourg Observers, 15 May 2020): <https://strasbourg observers.com/2020/o5/15/atv-zrt-v-hungary-a-missed-opportunity-to-address-hungarysoppressive-media-act/>; V Junod and O Simon, 'Abdyusheva and Others v. Russia: A Sadly Missed Opportunity' (Strasbourg Observers, 8 January 2020): <https://strasbourgobservers. com/2020/o1/o8/abdyusheva-and-others-v-russia-a-sadly-missed-opportunity/>; 
commentators, as well as representatives of civil society, defence lawyers, victims and concerned member of the public, are not satisfied with the level of the Court's engagement with various socio-legal issues. However, more often than not, the source of this dissatisfaction rests in the fact that various stakeholders reserve a significantly different role for the Court. The ECtHR needs to balance these different approaches and offer, not ideal, but appropriate solutions. So, what in one person's eyes can be a 'missed opportunity', someone else might not see as an opportunity at all. Those academics who speak of 'missed opportunities' would wish the ECtHR to do 'more' to protect human rights and do it 'better' - whatever these terms may mean to each one of us. The Court is looking for ways to enhance its ability strategically to impact human rights standards in Europe. There are a few examples where the Court changed its working methods with a view to safeguarding the human rights standards in the respondent states on a larger scale and, in a sense, maximise the impact of its practice. Two judicial innovations immediately come to mind - pilot judgments and enhanced interim measures.

While both these procedures push the boundaries of the Court's influence, their desirability can be disputed. We leave the pilot judgment procedure for another occasion and we are focusing here on interim measures. These measures are a unique tool that can help the Court impact an ongoing situation as this unravels, rather than provide ex post facto redress. With the ongoing COVID-19 crisis and the post-war situation in Nagorno-Karabakh, one can ask whether interim measures are fit for purpose as a means to protect human rights. In recent years, the ECtHR has started issuing interim measures of general character in inter-state cases related to armed conflicts in Europe. However, as we aim to show with this editorial note, it is not universally accepted that this opportunity is worth seizing. Before inviting our readers to consider our two different and, to a significant extent, diverging lines of reasoning, we provide below a brief overview of the evolution of interim measures within the ECHR system.

F Staiano, 'Yeshtla v. the Netherlands: A Missed Opportunity to Reflect on the Discriminatory Effects of States' Social Policy Choices' (Strasbourg Observers, 8 March 2019): <https:// strasbourgobservers.com/2019/o3/o8/yeshtla-v-the-netherlands-a-missed-opportunityto-reflect-on-the-discriminatory-effects-of-states-social-policy-choices/>; E Várnagy, ' $\mathrm{X}$ and Y v North Macedonia: A Missed Opportunity to Improve the Case Law on Anti-Roma Custodial Violence' (Strasbourg Observers, 27 January 2021): <https://strasbourgobservers. $\mathrm{com} / 2 \mathrm{O} 21 / \mathrm{ol} / 27 / \mathrm{x}$-and-y-v-north-macedonia-a-missed-opportunity-to-improve-the-caselaw-on-anti-roma-custodial-violence/>. 
Interim measures are provided by Rule 39 of the Rules of Court. They are issued in circumstances where the immediate risk of potential human rights violations is present. The Court's interim measures are binding; thus, the failure to comply with such measures can breach Article 34 of the Convention. ${ }^{2}$

Over the years, the ECtHR has clearly and consistently expanded the scope of interim measures in three different directions. First, the Court has applied interim measures in relation to ECHR Articles which previously were not considered suitable for such protection. Traditionally, the ECtHR requested interim measures in cases in which the applicant was facing an immediate danger of torture or death, mostly in the context of non-refoulement. Later, the Court started using interim measures in cases concerning Article 8, when deportation, for example, risked destroying the applicant's family life, and Article 6, when the actions of the state could lead to a flagrant denial of justice. More recently, the Court extended the scope of interim measures even further. In at least two cases, the Court granted interim measures to protect freedom of expression under Article 10 EC HR. In Rustavi 2 Broadcasting Company LTD and others $v$ Georgia, the Court issued interim measures preventing the authorities from closing one of the TV stations in Georgia. ${ }^{3}$ In the pending case of Sedletska $v$ Ukraine, ${ }^{4}$ the Court prevented the Ukrainian authorities from accessing the journalistic sources of an applicant. Whether violations of freedom of expression can lead to an immediate, serious and irreparable harm is debatable. Yet, what is quite evident is that the ECtHR is broadening the application of interim measures. While interim measures started as a very narrow and clearly defined tool, usually dealing with cases of extradition or deportation, it grew into a mechanism that can be applied to many serious cases.

Second, by means of interim measures, the Court is requesting the Contracting Parties to undertake a broad spectrum of obligations which previously would not fall within the scope of interim measures. Initially, the Court would demand states to abstain from refoulement until it examines the merits of a case. ${ }^{5}$ However, in more recent cases the Court has requested national authorities to move, for example, the applicant from a prison to a civilian

Mamatkulov and Askarov v Turkey [GC] $46827 / 99$ and 46951/99 (ECtHR, 4 February 2005) paras 128-129. Rustavi 2 Broadcasting Company Ltd and Others v Georgia 16812/17 (ECtHR, 18 July 2019) para 232.

4 Sedletska $v$ Ukraine 42634/18 (pending application): <http://hudoc.echr.coe.int/ eng?i=0o1-188248>.

$5 \quad$ See, Soering $v$ the United Kingdom 14038/88 (ECtHR, 7 July 1989) para 24. 
hospital ${ }^{6}$ or to provide legal aid. ${ }^{7}$ The ECtHR has recently granted interim measures following a request by the representative of Aleksey Navalnyy, the opposition leader in Russia. Navalnyy was poisoned in Russia and the Court requested the Russian authorities:

- to ensure that the applicant's family (wife) has access to his medical file from Omsk hospital;

- $\quad$ to ensure that the medical practitioners appointed by the applicant's family have access to him in order to examine him and conclude if the applicant is fit for transfer for further treatment in Germany;

- to inform the Court of the medical treatment the applicant receives, if any, and his current condition. ${ }^{8}$

The Court's request to transfer the applicant to a foreign country for treatment is a clear extension of the usual scope of interim measures. This case is exceptional. The ECtHR would not demand other Russian patients to be transferred to Germany for treatment. This instance shows that the Court does not see itself restricted by a narrower reading of interim measures.

Third, arguably, the most significant development in relation to the Court's ability to influence the situation beyond a particular individual application is the recent practice to indicate interim measures of general application in relation to an indeterminate number of people in the context of inter-state cases. There are a few cases in which the Court deployed this particular type of interim measures: Georgia v Russia (II), ${ }^{9}$ Ukraine v Russia,${ }^{10}$ Armenia v Azerbaijan ${ }^{11}$ and Armenia $v$ Turkey. ${ }^{12}$ In 2020, the Court issued interim measures in two interstate cases concerning the armed conflict in the Nagorno-Karabakh region. In the case of Armenia v Azerbaijan, the Court requested both parties:

to refrain from taking any measures, in particular military action, which might entail breaches of the Convention rights of the civilian population,

$6 \quad$ Kondrulin v Russia 12987/15 (ECtHR, 20 September 2016) para 21.

$7 \quad$ Xv Croatia 11223/04 (ECtHR, 17 July 2008) para 61.

8 ECtHR, press release issued by the Registrar of the Court, 'The Court Grants an Interim Measure in Favour of Aleksey Navalnyy', ECHR 235(2020), 21 August 2020: <http://hudoc. echr.coe.int/eng-press?i=003-6770533-9044388>.

9 Georgia v Russia (II) [GC] 38263/o8 (ECtHR, 21 January 2021) para 5.

$10 \quad$ Ukraine $v$ Russia (I) [GC] 20958/14 and 38334/18 (ECtHR, dec, 16 December 2020) para 5. The merits of the case are pending before the Court.

11 Armenia $v$ Azerbaijan 42521/20 (pending application).

12 Armenia $v$ Turkey 43517/20 (pending application). 
including putting their life and health at risk, and to comply with their engagements under the Convention, notably in respect of Article 2 (right to life) and Article 3 (prohibition of torture and inhuman or degrading treatment or punishment) of the Convention. ${ }^{13}$

The Court extended these measures in the case of Armenia v Turkey by addressing them to 'all States directly or indirectly involved in the conflict, including Turkey'.14

The interim measures in all mentioned inter-state cases have certain clear similarities: both the applicant and the respondent states are instructed to comply with the Convention, in particular with the most crucial Articles 2 (right to life) and 3 (prohibition of torture). Interim measures in all these cases are rather abstract and open to many possible interpretations. These measures are not directed at protecting some particular known individual but they rather cover an indefinite number of events and beneficiaries which can be hard to identify. In a sense, they involve a degree of speculation as to future events in the framework of the armed conflict where states will have to act in conformity with the ECHR. Under such circumstances, the Court will have to engage with intensive fact-finding missions to be able to decide conclusively and convincingly whether the Contracting Parties have or have not put the life and health [of the civilian population] at risk..$^{15}$ Moreover, in Armenia v Turkey, the Court also directed these measures to an indefinite number of potential respondent states.

In the past, interim measures were rather rarely employed, only in cases with clearly identifiable immediate risk to important rights, mostly concerning the life and health of the applicant. This ECtHR-created tool was originally aimed at producing individualised effects. Therefore, interim measures were narrow and custom-made. The Court's desire to influence ongoing crises prompted it to widen its approach to interim measures. Perhaps, this effort was partially inspired by a fear not to miss an opportunity to 'do good' and to prevent human rights violations. With this in mind, we are returning now to the title of this editorial note and asking whether indicating interim measures of general application is an 'opportunity' that it would have been better for the ECHR system if the Court had decided to 'miss'. Relying on previous,

\footnotetext{
13 ECtHR, press release issued by the Registrar of the Court, "The Court Grants an Interim Measure in the Case of Armenia v. Azerbaijan, ECHR 265(2020), 3o September 2020: <http:// hudoc.echr.coe.int/eng-press?i=0o3-6809725-9108584>.

14 ECtHR, press release issued by the Registrar of the Court, 'The Court's Decision on the Request of an Interim Measure Lodged by Armenia against Turkey', ECHR 276(2020), 6 October 2020: $<\mathrm{http} / /$ hudoc.echr.coe.int/eng-press?i=003-6816855-9120472>. 
more detailed, notes of ours, we are giving below two different opinions. These opinions result, not so much from a different identification of the issues and trade-offs at stake or of the conflicting interests but, primarily, from a different establishment of priorities translated into different suggestions as to how interim measures should be deployed.

\section{$3 \quad$ Why Should the Court Miss Opportunities Sometimes? ${ }^{16}$}

Interim measures are granted by the ECtHR immediately after an application has been submitted or even before that. The key purpose of interim measures is to ensure the effectiveness of human rights adjudication. Interim measures should be used to prevent clearly defined irreparable harm, and to maintain human rights practical and effective. Such interim measures guarantee that human rights adjudication remains meaningful and saves the option for the parties to resort to restitutio in integrum if the acts of the respondent party are found to be in breach of the rights enshrined in the Convention. The vast majority of interim measures oblige the addressee not to worsen the situation at hand. ${ }^{17}$ More rarely, the Contracting Parties are asked to fulfil certain duties. ${ }^{18}$ Simple obligations prescribing the respondent state not to act are a preferred option because such obligations are easier to formulate, but also to assess compliance with at a later stage.

The desire to broaden the Court's influence can turn clear and executable interim measures into generic and declaratory statements with unclear legal value. Although the Court would seemingly seize more opportunities to protect human rights, this strategy will backfire because interim measures will lose their character of a sharp, clear and rarely used tool. In many cases described above, the Court simply asks states to comply with Articles 2 and 3 of the Convention. The Contracting Parties should comply with these Articles simply by virtue of their signing and ratifying the ECHR, irrespective of interim

16 This sub-section relies on arguments made by $\mathrm{K}$ Dzehtsiarou in these sources: $\mathrm{K}$ Dzehtsiarou, 'Can the European Court of Human Rights Prevent War? Interim Measures in Inter-State Cases' (2016) Public Law 254; K Dzehtsiarou, 'Catch 22: The Interim Measures of the European Court of Human Rights in the Conflict between Armenia and Azerbaijan' (Strasbourg Observers, 9 October 2020): <https://strasbourgobservers.com/2020/10/o9/ catch-22-the-interim-measures-of-the-european-court-of-human-rights-in-the-conflictbetween-armenia-and-azerbaijan/>. The sole author of this sub-section is K Dzehtsiarou.

17 For example, preventing extradition or deportation.

18 For example, transferring a prisoner to a civil hospital. 
measures. ${ }^{19}$ Does the lifting of such interim measures mean that the states are no longer under the obligation to comply with Articles 2 and 3 ?

Interim measures can only achieve their purpose of ensuring the effectiveness of human rights adjudication if they are considered (not merely declared) legally binding and are routinely followed by the ECHR parties. In the past, the Court's interim measures enjoyed a high level of compliance. The compliance rate with interim measures has been more than 99 per cent while each instance of non-compliance triggered an immediate negative reaction from the Court. ${ }^{20}$ The compliance rate is important because the Court can only effectively impact the ongoing situation if states comply with such measures immediately. Therefore, clarity, simplicity and the low cost of interim measures can help ensure that states comply with them.

The ECtHR must consider the long-term consequences of its judgments and this, almost inevitably, means that the Court should miss some opportunities to set higher human rights standards or engage in some ongoing crises. The example of interim measures in inter-state cases illustrates this point very well. When the Court requested general interim measures in the case of Georgia v Russia (II) it effectively ruled that in all other armed conflicts in Europe, if requested, it will have to issue interim measures. It is hardly possible to imagine that the Court will be able to reject a request like that after setting such a precedent. It is also clear that it is unlikely that these measures are capable of having an impact on the behaviour of the parties in any significant sense. After the interim measures were granted in Armenia v Azerbaijan, the Nagorno-Karabakh conflict continued for a considerable period of time. Thus, the precedents set by the Court 'bind' it to continue issuing interim measures even if these have unclear chances of success. This is diluting the effectiveness of interim measures as a whole.

The Court's interim measures in high profile cases and in cases related to freedom of expression might create a different challenge. It is difficult for the Court to explain why it issues interim measures in some cases and does not do the same in other, comparable ones. Especially since such explanation comes

19 Article 1 ECHR.

20 'While prima facie the compliance rate seems extremely high (99\%), about $70 \%$ of the incompliances have been committed over the past 12 years (1999-2010), which is rather awkward in the light of the fact that although it has been established (since 2003) that non-compliance can generate the violation of Article $34 \mathrm{ECHR}$, the tendency not to follow the orders of provisional measures continues to increase.' Y Haeck, C Burbano Herrera and L Zwaak, 'Strasbourg's Interim Measures under Fire: Does the Rising Number of State Incompliances with Interim Measures Pose a Threat to the European Court of Human Rights?' (2011) European Yearbook of Human Rights 375, 380. 
in a form of short press-releases prepared by the ECtHR. Why did the Court request the transfer of Aleksey Navalnyy to Germany when it would clearly not do the same in the case of any other victim of torture or ill-treatment in Russia? Of course, there is a strong argument that suggests that, if free media or opposition voices are destroyed in a given country, the Court's subsequent judgment might be too little too late. The Court has to maintain a very delicate balance between principled and coherent decision-making and its ability to make a change here and now.

\section{Interim Measures of a More General Nature (In Inter-State} Disputes): Still Useful and Necessary ${ }^{21}$

In principle, provisional protection measures should be as concrete as is possible. This is also a matter of legal certainty. To a significant extent, the concreteness of interim measures depends on the specifics of a case. If an inter-state case concerns (the risk of) widespread, systematic violations of the rights of a large number of persons, interim measures will most probably be non-customised, thus quite abstract. Still, such measures are helpful and, indeed, needed by all those (sometimes the general population) who may benefit from them. Admittedly, such general/abstract measures are more difficult to implement, and this may be perceived as having a reputational cost for the authority of the ECtHR. Yet, equally costly for the reputation of a human rights court can be inertia, particularly if this is, in a sense, the output of calculation prioritising institutional image-building over human rights protection. Another possible counterargument is that abstract interim measures are infertile, meaningless reminders of the human rights obligations of states; issuing such reminders is mainly the task of international political institutions - not of courts. Yet, even if the language of interim measures might sometimes resemble that of a resolution issued by an international political institution, the latter lacks the authority of a court of law speaking as the mouthpiece of the law (bouche de la loi). Interim measures do not merely have a weighty expressive function and symbolism that carries meaning and moral authority. They do not

21 This sub-section relies on arguments made by VP Tzevelekos in this note: VP Tzevelekos, 'On the Value of Interim Measures by the ECtHR on Inter-Sate Disputes' (Strasbourg Observers, 3 February 2021): <https://strasbourgobservers.com/2021/o2/o3/on-the-valueof-interim-measures-by-the-ecthr-on-inter-sate-disputes/>. The sole author of this sub-section is VP Tzevelekos. 
simply remind states of the law. They also declare that the law, and the scrutiny, accountability and stigma for offenders that it entails are present. Besides, how effective (abstract) interim measures will be also depends on the ECtHR itself. The Court can decide when examining the merits of a case over which it has issued interim measures how much weight shall be given to these measures. It can also decide whether conduct departing from the direction in which the interim measures are pointing can be an aggravating factor or, ultimately, consider such conduct for the purposes of finding a violation of the right to complaint before the ECtHR or of Article 46 ECHR. The monitoring and sanctioning of the breaches of interim measures can help increasing their effectiveness in the future.

Moreover, to duly assess the appropriateness of abstract interim measures in wars or similar generalised emergencies, it is important to manage expectations and see the bigger picture. A judgment on the merits over such an inter-state dispute will not necessarily be more effective than interim measures. Law and judicial decisions do not suffice on their own to remedy the unlawful consequences of highly politicised disputes (involving unlawful use of force). What can prevent and stop war or remedy its unlawful consequences is what the international legal system has never managed success(fully) to build, ie an effective system of collective security. The overall effectiveness and value of interim measures in complex and highly charged inter-state disputes cannot be assessed in abstract terms. Such interim measures should not be dissociated from the broader sociolegal environment within which they have been developed and called to produce effects. By delivering interim measures in circumstances of war, the ECtHR is performing its task as an international (rather than a quasi-constitutional) court. It is contributing - to the extent that it can and from the perspective of human right law - to international peace and security, which is a precondition for the enjoyment of human rights. In a sense, the ECtHR is taking a bullet for the team (ie the broader international legal order) and is filling the gap crated, inter alia, by the failures of the United Nations Security Council or the lack of compulsory jurisdiction of the International Court of Justice. This also explains why states feel the need to resort to oblique legal solutions by translating disputes primarily concerning jus ad bellum into human rights disputes. Admittedly, in such circumstances, interim measures are a surrogate solution; a much-needed substitute that the ECtHR should generously grant to the extent that human rights law is applicable. If a court like the ECtHR can exercise its authority to point in the direction of peace and human rights, then it is worthy of it. Even the slightest contribution is welcome and, indeed, necessary. Overall, the opportunity cost for the ECHR system is 
rather minor, in particular if one weighs this against the gravity and scale of human rights violations.

Kanstantsin Dzehtsiarou | ORCID: oooo-0oo1-9253-6109

Professor in Human Rights Law, University of Liverpool, Liverpool,

United Kingdom

k.dzehtsiarou@liverpool.ac.uk

Vassilis P Tzevelekos | ORCID: oooo-0oo3-4848-5863

Senior Lecturer in Law, University of Liverpool, Liverpool,

United Kingdom

v.tzevelekos@liverpool.ac.uk 